What to Listen For in Jazz 
This page intentionally left blank 


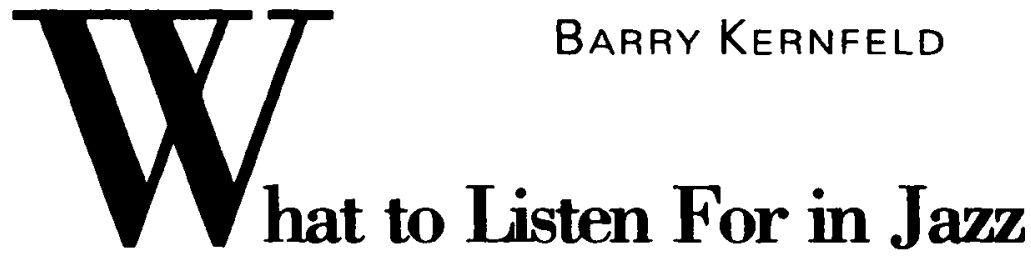


Published with assistance from the foundation established

in memory of Philip Hamilton McMillan of the class of 1894,

Yale College.

Copyright 1995 by Yale University.

All rights reserved.

This book may not be reproduced, in whole or in part.

including illustrations, in any form (bevond that

copving permitted by Sections 107 and 108 of the U.S.

Copyright Law and except by reviewers for the public

press), without written permission from the publishers.

Designed by Sonia L: Scanion.

Set in Bodoni type by The Composing Room of Michigan. Inc

Printed in the United States of America

Library of Congress Cataloging-in-Publication Data

Kernfeld, Barry Dean, 1950-

What to listen for in jazz / Barry Kernfeld.

p. $\mathrm{cm}$.

Includes discography (p. ) and index.

ISBN 978-0-300-07259-4

1. Jazz-Analysis, appreciation. I. Title.

\section{ML3506.K47 1995}

$781.65^{\prime} 17-d c 20 \quad 94-18324$

CIP

MN

A catalogue record for this book is available from the British Library.

The paper in this book meets the guidelines for permanence and durability of the Committee on Production Guidelines for Book Longevity of the Council on Library Resources. 